\title{
Copper, Zinc and Lead Enrichments in Sediments from Guacanayabo Gulf, Cuba, and Its Bioaccumulation in Oysters, Crassostrea rhizophorae
}

\author{
O. Díaz Rizo $\cdot$ S. Olivares Reumont $\cdot$ J. Viguri Fuente $\cdot$ O. Díaz Arado $\cdot$ \\ N. López Pino - K. D’Alessandro Rodríguez • D. de la Rosa Medero • \\ A. Gelen Rudnikas • G. Arencibia Carballo
}

Received: 11 December 2008/Accepted: 28 October 2009/Published online: 14 November 2009

(C) Springer Science+Business Media, LLC 2009

\begin{abstract}
Levels of iron, copper, zinc and lead were determined in sediments and soft tissue of the oyster Crassostrea rhizophorae collected from Guacanayabo Gulf, Cuba. Metal-to-Iron ratio in sediments shows an average enrichment for $\mathrm{Cu}(5,1), \mathrm{Pb}(11,7)$ and $\mathrm{Zn}(1,3)$ in the last 20 years. Metal concentrations found in soft tissue of $C$. rhizophorae are site dependent. The average biotasediment accumulation factors (BSAFs) obtained for $\mathrm{Fe}$, $\mathrm{Cu}$ and $\mathrm{Pb}$ are less than unity in all cases, indicating that only a little fraction of $\mathrm{Cu}$ and $\mathrm{Pb}$ in the sediments is bioavailable, independently of their enrichments. Zinc has an average BSAF value of 2.4 and may represent a serious impact in the area. The concentrations of zinc and copper in some of the oysters are above typical public health recommended limits.
\end{abstract}

Keywords Heavy metals · Oysters · Sediments · Guacanayabo Gulf

Guacanayabo is the largest gulf of Cuba. Its shores are part of three provinces: Camagüey, Las Tunas and Granma.

O. Díaz Rizo $(\bowtie) \cdot$ S. Olivares Reumont · O. Díaz Arado ·

N. López Pino · K. D’Alessandro Rodríguez ·

D. de la Rosa Medero · A. Gelen Rudnikas

Instituto Superior de Tecnologías y Ciencias Aplicadas, Salvador

Allende Ave. and Luaces, POB 6163, 10600 La Habana, Cuba

e-mail: odrizo@instec.cu

J. Viguri Fuente

Universidad de Cantabria, Ave. Los Castros s/n,

39005 Santander, España

G. Arencibia Carballo

Centro de Investigaciones Pesqueras, 5th Ave and 246 st.,

Playa, 17100 La Habana, Cuba
Hundreds of rivers and streams have its exit outlets in Guacanayabo waters, including Cauto River-the largest river of Cuba. The gulf area is superior to $8,000 \mathrm{~km}^{2}$ and the deep range between 2 and $13 \mathrm{~m}$. Those characteristics, jointly with an average temperature around the $25^{\circ} \mathrm{C}$ and an annual average oxygen dissolved concentration above five, create an historical habitat for species of high relevance in the Fishery Industry and so for the breading. Previous study of Guacanayabo Gulf coast sediments (Arencibia et al. 1988) reported the concentrations of $\mathrm{Al}, \mathrm{Pb}, \mathrm{Fe}, \mathrm{Zn}$ and $\mathrm{Cu}$ using Atomic Absorption Spectrometry (AAS). According to obtained results, the Guacanayabo Gulf was considered unpolluted.

In the last two decades, different industries around Guacanayabo Gulf (metal platting, tanneries, battery and textile plants, etc.) were installed. The aim of the present study was the investigation of the current state of heavy metal pollution of Guacanayabo Gulf coast sediments, taking into account the decrease of species capture in the last few years. Additionally, the determination of metal content in the soft tissue of a filter feeder mollusk, the oyster Crassostrea rhizophorae, collected in practically all studied stations was included. This specie has been considered as a useful sentinel of contamination (at leads for $\mathrm{Cu}$ and $\mathrm{Zn}$ ) in tropical and subtropical coast (Soto-Jiménez et al. 2001), consequently it could represent a good biomonitor of bioavailable metals present in waters and sediments.

\section{Materials and Methods}

The surface sediments were collected using a Van Veen snapper in 7 points of the gulf (Fig. 1) during the same journey. Stations were selected near to the outlets of the 
Fig. 1 Location of studied stations in Guacanayabo Gulf

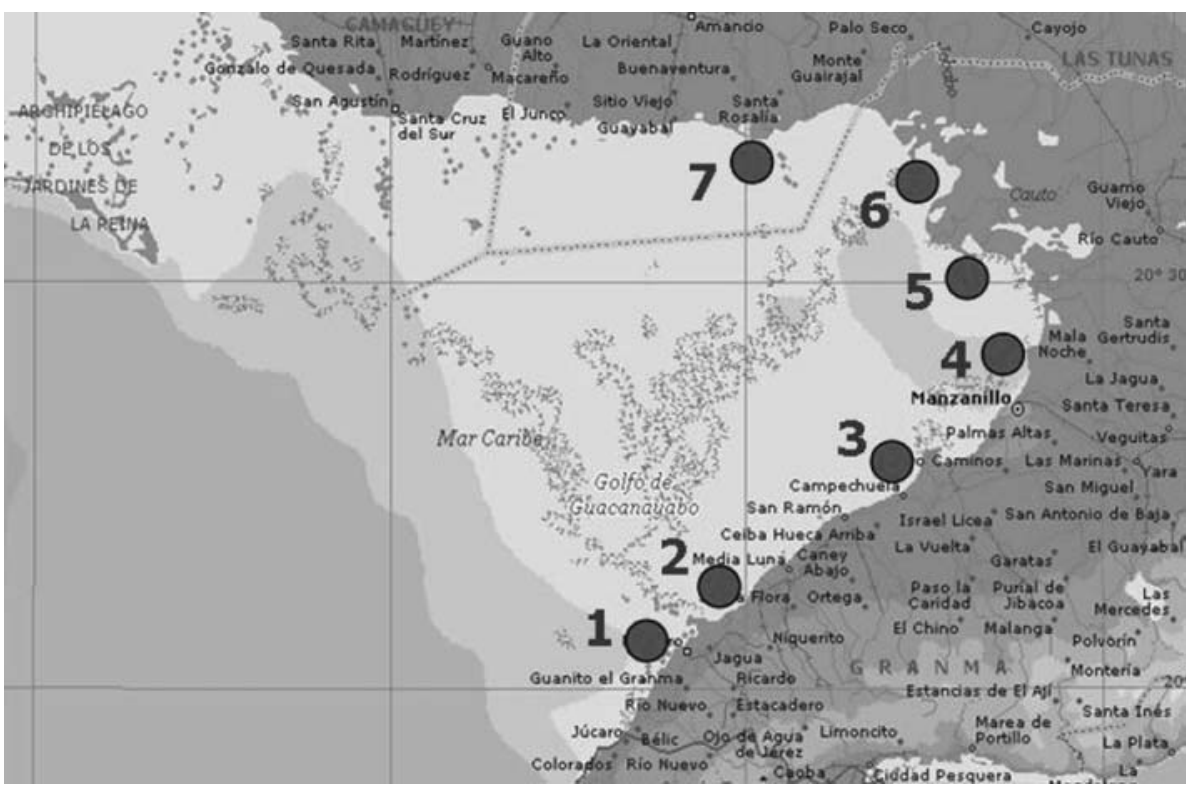

main rivers and the drainage and sewage systems of Manzanillo city, practically in the same places studied in 1988. All samples were dried at $50^{\circ} \mathrm{C}$. Large rock debris; mollusk skeletons and organic debris were removed before sieving. The fraction smaller than $1 \mathrm{~mm}$ was ground to a fine powder $(<63 \mu \mathrm{m})$ in an agate mortar. The pulverized samples were newly dried at $60^{\circ} \mathrm{C}$ until obtaining a constant weight.

The heavy metal concentrations were estimated by XRay Fluorescence Analysis (XRF) using the Certified Reference Materials (CRM) IAEA-SL-1 "Lake Sediment" (Dybczynski and Suschny 1974), IAEA-Soil-5 (Dybczynski et al. 2007), IAEA Soil-7 (Pszonicki 1984), BCR-2 "Basalt Columbia River" (Wilson 1997) and BCSS-1 "Marine sediment" from the Canadian National Research Council as standards. All samples and CRM were mixed with cellulose (analytical quality) in proportion $4: 1$ and pressed at 15 tons into the pellets of $25 \mathrm{~mm}$ diameter and 4-5 mm height. Pellets were measured using Canberra $\mathrm{Si}(\mathrm{Li})$ detector $(150 \mathrm{eV}$ energy resolution at $5.9 \mathrm{keV}$, Be window thickness $=12.0 \mu \mathrm{m}$ ) coupled to a MCA. A ${ }^{238} \mathrm{Pu}$ $(1.1 \mathrm{GBq})$ excitation source with ring geometry was used. All spectra were processed with WinAxil code (Winaxil 2005). Detection Limits were determined according Padilla et al. (2007) (in concentration units) as $L_{\mathrm{D}}=3 \sigma / \mathrm{mt}$, where $m$ is the sensibility in counts $\mathrm{seg}^{-1}$ per concentration unit, $\sigma$ is the standard deviation of the area of the background windows (peak window at 1.17 times the FWHM) and $t$ is the measuring time $(6 \mathrm{~h})$.

The accuracy was evaluated using the SR criterion, proposed by McFarrell et al. (Quevauviller and Marrier 1995):
$\mathrm{SR}=\frac{\left|C_{\mathrm{X}}-C_{\mathrm{W}}\right|+2 \sigma}{C_{\mathrm{W}}} \times 100 \%$

where $C_{\mathrm{X}}$-experimental value, $C_{\mathrm{W}}$-certified value and $\sigma$ is the standard deviation of $C_{\mathrm{X}}$. On the basis of this criterion the similarity between the certified value and the analytical data obtained by proposed methods is divided in three categories: $\mathrm{SR} \leq 25 \%=$ excellent; $25<\mathrm{SR} \leq 50 \%=$ acceptable, SR $>50 \%=$ unacceptable. The analysis of five replica of the CRM IAEA-356 "Polluted Marine Sediment" (IAEA 1994) is presented in Table 1. All heavy metals (Fe, $\mathrm{Cu}, \mathrm{Zn}$ and $\mathrm{Pb}$ ) determined by ES-method are "excellent" (SR $\leq 25 \%)$ and the obtained results shows a very good correlation $(R=0.9999)$ between certified and measured values.

The metal enrichment was calculated by normalizing the results to a reference metal, using the Enrichment Factor (Schropp et al. 1990):

$\mathrm{EF}=(X / Y)_{\text {sample }} /(X / Y)_{\text {background }}$

where $X$ is the concentration of potentially enriched metal and $Y$ is the concentration of the reference metal. If the EF value of an element is close to unity, it means that its observed concentration in sediment samples can be considered as crustal material. Enrichment value higher than unity indicated non-crustal contribution on the corresponding element concentration. The EF calculation depends on the background selection. Usually, the selection of results from previous study of the area of interest as background is more recommended (Vreca and Dolenec 2005). In the present study, the AAS results (Arencibia et al. 1988) were used as background values. In order to assess the possible 
Table 1 XRF analysis of CRM IAEA-356 (mean \pm SD, $\mathrm{n}=5$, $\mathrm{mg} \mathrm{kg}^{-1}$ except $\mathrm{Fe}$ ), SR values and detection limits

\begin{tabular}{lllll}
\hline Metal & Certified value & Measured value & SR $(\%)$ & $L_{\mathrm{D}}\left(\mathrm{mg} \mathrm{kg}^{-1}\right)$ \\
\hline $\mathrm{Fe}(\%)$ & 2.41 & $2.57 \pm 0.19$ & 23 & 9 \\
$\mathrm{Cu}$ & 365 & $360 \pm 29$ & 17 & 16 \\
$\mathrm{Zn}$ & 977 & $958 \pm 45$ & 11 & 5 \\
$\mathrm{~Pb}$ & 347 & $362 \pm 22$ & 22 & 4 \\
\hline
\end{tabular}

anthropogenic impact, the use of $\mathrm{Fe}$ to normalize the trace metal contaminants is recommended (Mucha et al. 2003). Iron is abundant in the environment and is scarcely influenced by anthropogenic inputs because the natural high levels of this element (Villares et al. 2003).

Oysters Crassostrea rhizophorae were collected in the same sediment collection day. At each stations (except St. 3) adult specimens (4-7 cm in length) size were collected. In Station 3 no oysters were found, probably due to the substrate type or the presence of toxic loads prevailing in those waters and sediments. Specimens were rinsed with seawater and transported on ice in pre-cleaned polyethylene containers. In laboratory, soft tissue of 30 specimens by each station were cleaned with distilled water, isolated from the shells and pooled; then, they were weighed, lyophilized and homogenized in an agate mortar.

Oyster samples were then transferred to University of Cantabria, Spain, for chemical analyses. Methods for extracting heavy metals from tissue samples were derived from the US Environmental Protection Agency (EPA) standard method 3052 (EPA 1996). About $0.5 \mathrm{~g}$ dried sample was transferred into HP 500 vessel for digestion with $9 \mathrm{~mL}$ of ultra pure nitric acid. The vessels were then inserted into a microwave (CEM MARS 5X) and heated at a temperature profile reaching $180^{\circ} \mathrm{C}$ in approximately less than $5.5 \mathrm{~min}$ and remaining at $180^{\circ} \mathrm{C}$ for $9.5 \mathrm{~min}$ at $600 \mathrm{~W}$. After cooling, the vessel contents are filtered, centrifuged, diluted to volume, and then transferred into plastic containers and kept in refrigerator at about $4^{\circ} \mathrm{C}$ previous to analysis. All reagents were analytical grade or Suprapur quality (Merck, Germany). Milli-Q water (Millipore, Bedford, MA, USA) was used in all experiments. Cleaning of plastics and glassware was carried out by soaking in $14 \%(\mathrm{v} / \mathrm{v}) \mathrm{HNO}_{3}$ for $24 \mathrm{~h}$ and then rinsing with water.

Quantification of metals in the extract was performed using a combination of inductively coupled plasma emission spectrometry (ICP-AES) and mass spectrometry (ICP$\mathrm{MS})$. All digested samples were analyzed for $\mathrm{Fe}, \mathrm{Cu}$ and Zn by ICP-AES (Perkin Elmer plasma 400) due to the high contents in biologic samples according to the US EPA Method 6020A (EPA 2007a). ICP-AES was calibrated by standard addition methods and freshly prepared metal salt (Merck multielement standard) solutions. Practical minimum detection limits against replicated procedural blanks were $0.053 \mathrm{mg} \mathrm{L}^{-1}$ for $\mathrm{Cu}, 0.061 \mathrm{mg} \mathrm{L}^{-1}$ for $\mathrm{Fe}$ and $0.132 \mathrm{mg} \mathrm{L}^{-1}$ for $\mathrm{Zn}$. The $\mathrm{Pb}$ analysis was performed by ICP-MS (Agilent Technologies 7500ce model) according to the US EPA Method 6010C (EPA 2007b); analytical multielement standard solutions for ICP-MS were prepared by diluting a mixed standard solution. Minimum detection limit of $\mathrm{Pb}$ was $0.041 \mu \mathrm{g} \mathrm{L}^{-1}$. Concentrations reported are the mean and standard deviation of three replicate measurements (corrected for dilution when was necessary). Analytical quality was assured by using a certified reference sample of NIST CRM $1566 \mathrm{~b}$ oyster tissue. The percentage of recovery for all metals ranged between 85 and $110 \%$ of certified values.

In order to estimate the proportion in which metal occurs in the selected bivalve and associates sediment, the biota-sediment accumulations factors (BSAFs) were calculated for selected metals in the studied oysters according to the formula (Szefer et al. 1999):

$\mathrm{BSAF}=C_{\mathrm{X}} / C_{\mathrm{S}}$

where $C_{\mathrm{X}}$ and $C_{\mathrm{S}}$ are the mean concentrations of metal in the organism and in associated sediment, respectively.

\section{Results and Discussion}

The average $\mathrm{Fe}, \mathrm{Cu}, \mathrm{Zn}$ and $\mathrm{Pb}$ concentrations determined by ED-XRF in Guacanayabo Gulf coasted sediments are given in Table 2. $\mathrm{Fe}, \mathrm{Pb}$ and $\mathrm{Zn}$ distributions shows maximum in stations near of Manzanillo city ( 3 and 4), and $\mathrm{Cu}$ concentration is practically uniform in all studied

Table 2 Average concentrations (mean $\pm 1 \mathrm{SD}, \mathrm{n}=5, \mathrm{mg} \mathrm{kg}^{-1}$, except Fe) for heavy metals determined in Guacanayabo Gulf coast sediments

\begin{tabular}{|c|c|c|c|c|c|c|c|c|c|}
\hline \multirow[t]{2}{*}{ Metal } & \multirow[t]{2}{*}{ Station 1} & \multirow[t]{2}{*}{ Station 2} & \multirow[t]{2}{*}{ Station 3} & \multirow[t]{2}{*}{ Station 4} & \multirow[t]{2}{*}{ Station 5} & \multirow[t]{2}{*}{ Station 6} & \multirow[t]{2}{*}{ Station 7} & \multicolumn{2}{|c|}{ NOAA } \\
\hline & & & & & & & & ERL & ERM \\
\hline $\mathrm{Fe}(\%)$ & $2.4 \pm 0.1$ & $2.8 \pm 0.2$ & $4.3 \pm 0.2$ & $6.7 \pm 0.4$ & $5.2 \pm 0.3$ & $2.9 \pm 0.2$ & $3.6 \pm 0.2$ & - & - \\
\hline $\mathrm{Cu}$ & $163 \pm 14$ & $129 \pm 11$ & $169 \pm 14$ & $158 \pm 13$ & $169 \pm 14$ & $157 \pm 13$ & $186 \pm 15$ & 34 & 270 \\
\hline $\mathrm{Zn}$ & $60 \pm 4$ & $56 \pm 4$ & $90 \pm 6$ & $94 \pm 6$ & $92 \pm 6$ & $56 \pm 4$ & $60 \pm 5$ & 150 & 410 \\
\hline $\mathrm{Pb}$ & $29 \pm 3$ & $29 \pm 3$ & $37 \pm 4$ & $35 \pm 3$ & $21 \pm 3$ & $20 \pm 3$ & $24 \pm 3$ & 46.7 & 218 \\
\hline
\end{tabular}


stations. In order to evaluate if the metal concentrations found in the studied site are a sign of toxicity, the surface sediment concentrations of heavy metals are compared with benchmark sediment data, developed by the US National Oceanographic and Atmospheric Administration (NOAA) (Buchman 1999) which are to be used as screening values to assess the quality of sedimentary deposits. The indexes analyzed here (in increasing order of toxicity) were the Effects Range-Low (ERL) and the Effects Range-Moderate (ERM) for marine and estuarine ecosystems. According to NOAA classification, the Guacanayabo Gulf coast surface sediments are "moderately contaminated" with $\mathrm{Cu}$ (all stations). $\mathrm{Cu}$ is discharge particularly from metal platting industries (Sinem et al. 2000). Taking into account the existence of this type of industry near the Guacanayabo Gulf, its must be the reason of the observed behavior.

Calculating the Enrichment Factor respect to Fe for Zn, $\mathrm{Cu}$ and $\mathrm{Pb}$ using AAS results (Arencibia et al. 1988) as background (Table 3), we obtain the behavior of the metal increment in the last 20 years in the studied stations $\left(\mathrm{EF}_{20 \mathrm{y}}\right)$.

A considerable average enrichment for $\mathrm{Cu}$ (an average concentration increment in 5.1 times in 20 years) and $\mathrm{Pb}$ (11.7 times) is observed. This $\mathrm{Cu}$ enrichment justifies the classification of the Guacanayabo coast sediments as "moderately contaminated". On the other hand, the great enrichment rate determined for $\mathrm{Pb}$ is significant. At present time the sediments can be considered as "uncontaminated" by $\mathrm{Pb}$, but, if $\mathrm{Pb}$ input is not controlled, in a few years the $\mathrm{Pb}$ concentration in the sediments will be larger than ERL NOAA level.

Table $3 \mathrm{Zn}, \mathrm{Cu}$ and $\mathrm{Pb}$ average enrichments of the coast sediments in the last 20 years

\begin{tabular}{lllr}
\hline Metal & \multicolumn{2}{c}{ Average Metal-Fe ratio $^{\mathrm{a}}$} & $\mathrm{EF}_{20 \mathrm{y}}$ \\
\cline { 2 - 3 } & Arencibia et al. (1988) & Present study & \\
\hline $\mathrm{Zn}$ & 14.0 & 18.3 & 1.3 \\
$\mathrm{Cu}$ & 8.0 & 40.7 & 5.1 \\
$\mathrm{~Pb}$ & 0.6 & 7.0 & 11.7 \\
\hline
\end{tabular}

$\bar{a}$ Calculated using $\mathrm{Zn}, \mathrm{Cu}$ and $\mathrm{Pb}$ average concentrations in $\mathrm{mg} \mathrm{kg}^{-1}$ and $\mathrm{Fe}$ average concentration in $\%$
A little fraction of $\mathrm{Zn}$ content must have anthropogenic origin $(\mathrm{EF}=1.3) . \mathrm{Zn}$ is associated with discharges from various industries such as tannery, battery and textile. All mentioned industries exist near the Gulf. Then, the main $\mathrm{Zn}$ input must be the deficient treated industrial waste discharges.

Table 4 presents metal concentrations found in the soft tissue of the oyster Crassostrea rhizophorae in each possible studied station. The results have shown significant differences between stations in the accumulated concentrations of each of the trace metals in the oyster, except lead. Given the fact that accumulated concentrations are integrated records of the bioavailability of each metal to the oyster, it follows, therefore, that the bioavailability of the metals varies geographically in the Guacanayabo Gulf. The different metals show different patterns of bioavailability. Oysters from station 4 (nearly to Manzanillo city) often had the highest accumulated $\mathrm{Fe}$ and $\mathrm{Cu}$ concentrations, and oysters from station 7 had the highest $\mathrm{Zn}$ concentrations.

The reason for the observed geographical variation in the bioavailability of the metals is caused most probably by the input of these metals in dissolved and/or particulate form through anthropogenic activity in the Guacanayabo Gulf. Such activities include dredging, agricultural use of metal-containing fertilizers and pesticides, and the emission of untreated sewage and also metal contaminated effluents from medical use and industrial units.

The average metal concentrations in organisms and sediments from the studied stations were used for calculating BSAFs and are shown in Fig. 2. BSAF factor refers to the bioavailability of given metals presents in the sediment. The average BASFs obtained for $\mathrm{Fe}, \mathrm{Cu}$ and $\mathrm{Pb}$ were less than unity. The last must be an indicator that a little fraction of these metal contents presents in Guacanayabo Gulf coast sediments is bioavailable, independently their metal enrichments. On the other hand, $\mathrm{Zn}$ has an average BSAF value of 2.4 and must represent a serious impact in the area.

Oysters from the Guacanayabo Gulf are used as a local food source. Public health limits on the concentrations of toxic metals are usually quoted in terms of fresh (wet) weight. Cuban regulations (NC 2006) specify a maximum allowable limit for lead $\left(0.2 \mathrm{mg} \mathrm{kg}^{-1}\right)$. Limits for the rest

Table 4 Heavy metal average concentrations (mean $\pm 1 \mathrm{SD}, \mathrm{n}=3, \mathrm{mg} \mathrm{kg}^{-1}$ wet wt.) determined in Crassostrea rhizophorae from Guacanayabo Gulf

\begin{tabular}{|c|c|c|c|c|c|c|}
\hline Metal & Station 1 & Station 2 & Station 4 & Station 5 & Station 6 & Station 7 \\
\hline $\mathrm{Fe}$ & $34 \pm 1$ & $162 \pm 3$ & $278 \pm 4$ & $38 \pm 1$ & $88 \pm 2$ & $91 \pm 2$ \\
\hline $\mathrm{Cu}$ & $17 \pm 1$ & $41 \pm 1$ & $53 \pm 2$ & $29 \pm 1$ & $28 \pm 1$ & $26 \pm 1$ \\
\hline $\mathrm{Zn}$ & $88 \pm 1$ & $119 \pm 2$ & $191 \pm 3$ & $82 \pm 1$ & $162 \pm 2$ & $219 \pm 3$ \\
\hline $\mathrm{Pb}$ & $0.08 \pm 0.01$ & $0.13 \pm 0.01$ & $0.07 \pm 0.01$ & $0.05 \pm 0.01$ & $0.06 \pm 0.01$ & $0.09 \pm 0.01$ \\
\hline
\end{tabular}




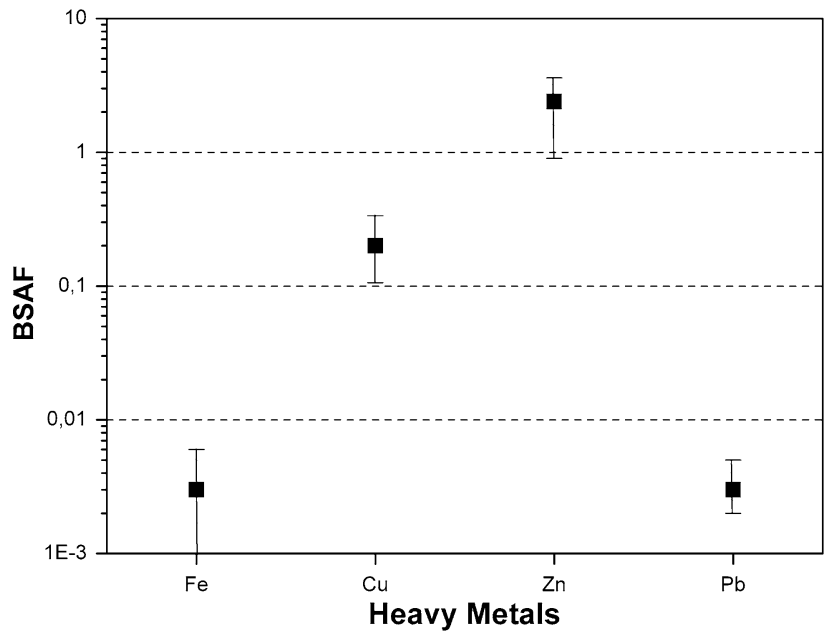

Fig. 2 Biota-sediment accumulation factor values (main and range) in Crassostrea rhizophorae

of the elements have not been specified. On the other hand, the limits recommended by the Ministry of Agriculture Fisheries and Food (MAFF) for England and Wales are $20 \mathrm{mg} \mathrm{kg}^{-1}$ wet wt. for copper, $50 \mathrm{mg} \mathrm{kg}^{-1}$ wet wt. for zinc (MAFF 1981), and $1 \mathrm{mg} \mathrm{kg}^{-1}$ wet wt for lead (MAFF 1982), although it is recognized that certain seafoods, especially shellfish, may exceed these limits for copper without toxic effects (MAFF 1981). Then, the wet weight concentrations of Guacanayabo oysters, in average, reached $164 \mathrm{mg} \mathrm{Zn} \mathrm{kg}^{-1}, 34 \mathrm{mg} \mathrm{Cu} \mathrm{kg}^{-1}$ and $0.07 \mathrm{mg} \mathrm{Pb}$ $\mathrm{kg}^{-1}$ wet wt. The most contaminated oysters from the Guacanayabo Gulf, therefore, may carry a health risk from their $\mathrm{Zn}$ and $\mathrm{Cu}$ concentrations.

\section{References}

Arencibia G, Isaac M, González H (1988) Metal behaviour in coast sediments from Guacanayabo Gulf. Cuban J Chem IV 3:39-45 (in Spanish)

Buchman MF (1999) NOAA screening quick references tables. NOAA HAZMAD report 99-1, Seattle, WA, USA, p 12

Dybczynski R, Suschny O (1974) Reference material SL-1 "lake sediment". Report IAEA/RL/64, IAEA, Vienna

Dybczynski R, Tugsavul A, Suschny O (2007) Soil-5, a new IAEA certified reference material for trace elements determinations. Geostand Geoanalytical Res 3:61-87

EPA (1996) SW-846 test methods for evaluating solid waste, physical/chemical methods, method 3052: microwave assisted acid digestion of siliceous and organically based matrices. http://www.epa.gov/osw/hazard/testmethods/sw846/pdfs/3052. pdf. Accessed 9 Jan 2008
EPA (2007a) SW-846 test methods for evaluating solid waste, physical/chemical methods, method 6020A: inductively coupled plasma-mass spectrometry. http://www.epa.gov/osw/hazard/test methods/sw846/pdfs/6020a.pdf Accessed 9 Jan 2008

EPA (2007b) SW-846 test methods for evaluating solid waste, physical/chemical methods, method 6010C: inductively coupled plasma-atomic emission spectrometry. http://www.epa.gov/osw/ hazard/testmethods/sw846/pdfs/6010c.pdf Accessed 9 Jan 2008

IAEA (1994) Reference material IAEA-356 "polluted marine sediment". IAEA/AL/080 report, IAEA, Vienna

MAFF (1981) Survey of copper and zinc in food. Fifth report of the steering group on food surveillance. The working party on the monitoring of foodstuffs for heavy metals. Food surveillance paper No. 5. Her majesty's stationery office, London

MAFF (1982). Survey of lead in food. Tenth report of the steering group on food surveillance. The working party on the monitoring of foodstuffs for heavy metals. Food surveillance paper No. 10. Her majesty's stationery office, London

Mucha AP, Vasconcelos MTSD, Bordalo AA (2003) Macrobenthic community in the Douro estuary: relations with trace metals and natural sediment characteristics. Environ Pollut 121:169-180

NC (2006) Norma Cubana-493. Metallic contaminant in foodsanitary regulation. Cuban national bureau of standards. ICS: 67.020, Havana (in Spanish)

Padilla R, Markowicz A, Wegrzynek D, Chinea E, Bamford SA, Hernández D (2007) Quality management and method validation in EDXRF analysis. X-Ray Spectrom 36:27-34

Pszonicki L (1984) Reference material IAEA Soil-7. Report IAEA/ RL/112, IAEA, Vienna

Quevauviller Ph, Marrier E (1995) Quality assurance and quality control for environmental monitoring. $\mathrm{VCH}$, Weinheim

Schropp SJ, Lewis FG, Windom HL, Ryan JD, Calder FD, Burney LC (1990) Interpretation of metal concentration in estuarine sediments of Florida using aluminum as reference element. Estuaries 13:227-235

Sinem R, El-Agha O, Zararsiz A, Hatice A, Tuncel G (2000) Investigation of the sediment pollution in Izmir bay: trace elements. Spectrochim Acta Part B 55:1151-1164

Soto-Jiménez M, Páez-Osuna F, Morales-Hernández F (2001) Selected trace metal in oysters (Crassostrea iridescens) and sediments from the discharge zone of the submarine sewage outfall in Mazatlán Bay (southeast Gulf of California): chemical fractions and bioaccumulation factors. Environ Pollut 144: $357-370$

Szefer P, Ali AA, Ba-Haroon AA, Geldon J, Nabrzyski M (1999) Distribution and relationships of selected metals in molluscs and associated sediments from the Gulf of Aden, Yemen. Environ Pollut 106:299-314

Villares R, Puente X, Carballeira A (2003) Heavy metals in sandy sediments of the Rias Baixas (NW Spain). Environ Monit Assess 83:129-144

Vreca P, Dolenec T (2005) Geochemical estimation of cooper contamination in the healing mud from Makirina Bay, central Adriatic. Environ Int 31:53-61

Wilson SA (1997) The collection, preparation and testing of USGS reference material BCR-2, Columbia River, Basalt, U.S. Geological survey open-file report $98-00 x$

WinAxil (2005) WinAxil code. Version 4.5.2. WinAxil, CANBERRA MiTAC 